\title{
On Control Strategy to Information Risk of Logistical outsourcing
}

\author{
Weixia Yang \\ School of business \\ Xian International University \\ Xi'an, China \\ wxyang741117@163.com
}

\begin{abstract}
Logistics outsourcing is the evolution of formation and development of the third party logistics enterprise and the objective demand of enterprise produced in the new market competition. The logistics outsourcing plays an important role for enterprises to focus on the core business. Their condensed utmost resource improves the efficiency of resources. Therefore, enterprise must strengthen the overall arrangement and coordination and communication in the process of logistics outsourcing, and formulate prevention strategies of outsourcing information risk suiting one's measures to local conditions, in order to further enhance their own core competitive ability. In the paper, the author analyze the information risk existing in the process of logistics outsourcing. Finally the author puts forward a series of control strategy to information risk, to break the bottleneck and improve the level of logistical outsourcing.
\end{abstract} strategy

Keywords- logistical outsourcing; information risk; control

\section{INTRODUCTION}

With the advent of economic globalization, focusing resources and energy on enterprise's core competitiveness business, the production or selling enterprise outsource the logistics business that is not their comparative advantage to the professional third party logistics company. It is an way which can accelerate speed of material flow, save logistics cost and improve the capital turnover rate, and it can bring convenie-nce and benefits a lot for both the supply and demand. At the same time, enterprises also face a lot of risks in the process of logistical outsourcing. [1] Of all the risks, information risk is one of the most difficult to control. This is because that, on the one hand, the process of outsourcing logistics is actually a process of information flow. In this process, a lot of enterprises information such as customer information, product information, and management program must be shared with the logistics enterprises. But in actual operation, for their own interests the two sides will often keep the core information, at last information asymmetry arise. With the deepening of the outsourcing process, the problem will produce that the information communication and feedback mechanism is not perfect. On the other hand, in logistical outsourcing process, transmitting information between enterprises and the third party logistics enterprises also increases the risk of leakage about enterprise core technology and business secret, which can cause great losses to the enterprise. So the research on how to control the information risk of enterprise logistics outsourcing has a certain practical significance to outsourcing implementation smoothly..

\section{SIGNIFICANCE OF BUSINESS'S LOGISTICAL OUTSOURCING}

\section{A. Improve the Competitiveness of Enterprises}

Firstly, after enterprise outsources logistics business, it will concentrate the limited human, financial, material resources on its core business, and optimize the allocation of enterprise's resources. Secondly, Logistics enterprises will provide the most appropriate, the most excellent logistics services to enterprise. Thus on the one hand, enterprises focus on core business, improving product performance and reducing the price of products. On the other hand, logistics enterprises can ensure logistics business to develop smoothly, and provide value-added service such as on-time delivery, after-sale service for customer. Enterprise effectively configures and integrates internal resources and external resources, that makes both the product and the service maintaining competitive, so as to the overall competitiveness of enterprises is improved.

\section{B. Reduce Investment of Enterprise}

Outsourcing logistics business to the third party logistics companies, enterprises can no longer keep vehicles, forklifts, cranes, transport vehicles and other basic logistics infrastructure, at the same time, enterprises can also passed the investment of the construction of logistics information system on to the third party logistics company. [2]The third party logistics company can also achieve economies of scale through the acceptance of different enterprises logistics outsourcing , and achieve cost savings.

\section{Improve Customer Satisfaction}

At present, the competitive advantage of enterprises is embodied in the low cost, high quality, short order cycle, on time delivery etc. Low price, good quality of products can be produced by the enterprise by the process of production and research. But in short order cycle, on time delivery and low failure rate of the products and after sale service and other aspects of production enterprises did not just as one wishes, which affect customer satisfaction to a great extent. Especially in the increasingly fierce market competition 
environment, customer demand for services has become increasingly high, even more than the requirements of production price. The professional third party logistics can give customers a good logistics services, including delivery performance, shorten order cycle, good customer service, even personalized logistics services such as timing distribution, that effectively meet the diverse needs of customers, reduce customer complaint rate, greatly improve customer satisfaction. [3].

\section{Increase the Social Benefits}

After enterprise outsources logistics business, the third party logistics company will not only make the reasonable mode of transport and transport routes through professional analysis, but also reduce the phenomenon of vehicle emptyloaded and circuitous transportation through the joint distribution, cross docking and other distribution methods. [4]To reduce the number of distribution vehicles can alleviate the city traffic pressure, improve vehicle efficiency, reduce resource consumption, reduce the discharge of automobile tail gas and to reduce noise pollution, that is conductive to protecting and improving the environment, realize the sustainable development of economy and environment.

\section{E. Improve Operation Flexible of Enterprise}

Enterprises outsource logistics business to the third party logistics company, thus a large number of non professional business are completed by the partners, and it can simplify its administrative structure, make the organization structure of company situated at a height of more flexible. The problems that tissue response too slowly and tissue is lack of innovative spirit have been solved.

\section{THE EXISTING INFORMATION RISK IN PROCESS OF LOGISTICS OUTSOURCING}

\section{A. The Information Can Not Be Shared in Time}

On the one hand, because the outsourcing company and the third party logistics enterprise are not identical in information management system, it lead the outsourcing enterprise goods information and customer relationship management information not to transmit to the third party logistics enterprise. On the other hand, after the third party logistics enterprises sent out goods, they can not take corresponding information such as customer service attitude and product satisfaction degree feedback to the logistics outsourcing enterprises timely. [5]

\section{B. Information Is Distorted or Out of Control}

With logistics is outsourced, the executive body transfers. On the one hand, due to poor information or not smooth information, plus control technology and monitoring means is backward, it is difficult for enterprises to conduct a comprehensive monitoring and tracking management to the whole process of after sale service, so that enterprises will be difficult to control and grasp it, if the business and logistics enterprises appear illegal behavior. On the other hand, after logistics outsourcing, enterprise can not directly obtain relevant information on product quality and service attitude of the relevant customer, ultimately these affect development of the enterprise's core business.

\section{The Core Data Is Lost}

Because the logistics is inseparable with capital flow and information flow, logistics department must closely contact with other departments, logistics links contains a large number of business secrets, including sales data, customer order data, customer and distribution channel, customer product price and discount information and so on. [6] Logistics outsourcing means that the information integrating with logistics will be grasped by the third party company. If these information is leaked, it will bring considerable risks to the enterprise. And the range of logistics service providers involved in the information is more wide, the risk that information is disclosed is greater.

\section{REASON OF FORMATION INFORMATION RISK IN LOGISTICS OUTSOURCING}

Logistics outsourcing is an open, complex system, it is business portfolio driven by interest, and consisted by enterprises and logistics service providers who has the different core competence. The interaction relationship between the principal and agent enterprises is very complex, coupled with the human error, institutional constraints, the backward ideas and technology management defects and other factors. In the process of mutual activities, there must be many potential information sources of risk environment, personnel, organization, decision, culture and so on.

\section{A. Environmental Factors Within and External of the Enterprise}

In the internal environment, factors causing information risk in the enterprise logistics outsourcing is mainly reflected in: firstly, corporate culture is different. Secondly, employees resistances transmitting information. In external environment factors causing information risk in the enterprise logistics outsourcing is mainly reflected in: natural environment, political and economic environment, market environment, legal environment and other factors on the production of enterprise logistics outsourcing.

\section{B. Management Factors in Outsourcing}

In the decision-making and implementation of the outsourcing process, the management problems of the enterprise itself leading information risk of outsourcing may have the following: first is that the outsourcing decisionmaking is mistake. Second is that the logistics service provider is too single. Third is that the cooperation is not stable. Forth they have reached a consensus onsomeissues. A lot of practice proved, cooperation between the two sides can not reach a consensus that is the most common cause. Fifth is the outsourcing contract is not standardized; sixth is there is not the reasonable performance evaluation.

\section{Factors in The Process of Information Transferring}

Factor in the transmitting information process are as follows: First is that information communication and 
feedback mechanism is not perfect. Second is that unsymmetrical information and incomplete information is existing.

\section{CONTROL INFORMATION RISK STRATEGY OF THE ENTERPRISE LOGISTICS OUTSOURCING}

The implementation of information management can set up a quick information feedback system of garment enterprises, thus it can greatly improve the response speed to market, reduce risk and cost of the operation, provide the integrity data of the production management for enterprise decision makers, each business links can also be combined organically, business statistical analysis can be automated.

\section{A. Establishing an Effective Information Sharing Mechan- ism}

In the process of logistics outsourcing, information risk because of Information asymmetry is the most common risk. [7]After logistics outsourcing, the two cooperation sides should promote information sharing mechanism, establish an information sharing system, timely, accurately share the transport costs, transport demand, transport planning, production plan and customer satisfaction degree and so on, such it can avoid potential problems. Enterprise should strengthen credit management of the two sides, increase credit cooperative. Partners should achieve mutual security in information sharing at the same time, if a party leaks the other party's commercial secrets, so the party must bear the corresponding legal responsibility.

\section{B. Forming a Strategic Alliance with the Third Party Logistics Enterprise}

Enterprise establish a close partnership with the third party logistics enterprise, that is an important means to reduce the risk of outsourcing, and Is key to the successful implementation of outsourcing. On the one hand the establishment of long-term strategic cooperative partnership helps to eliminate the information distortion through the exchange of information and communicate between member enterprises, so as to reduce uncertainty, reduce risk. On the other hand, the cooperation mechanism of benefit sharing and risk sharing can avoid information risk caused by the uncertainty generated from the moral risk and irresponsible [8].

\section{Establish Risk Management Team, Supervise Formulat- ion and Implementation of Contract}

Firstly, enterprise establish logistics outsourcing information risk management team, and the team identify, analysis, assess, control and treat the information generated in the process of logistics outsourcing risk, which will be conducive to systematize and normalize the prevention of the risk of logistics outsourcing. [9] Secondly, enterprise establish emergency mechanism of risk management with logistics service supplier, and it will can deal with risks by taking contingency measures designed, and effectively reduce risk losses of unexpected information to enterprise. Finally, enterprises should appoint experienced personnel, invite lawyers, consultants' negotiators and so on other professionals who consult with logistics service providers and carefully prepare the terms of the contract which clear the responsibilities and obligations of both parties. During the execution of the contract, enterprise strictly requires that suppliers complete logistics business in accordance with the contract requirements, constraints logistics suppliers to comply with the commitments, which guarantee the progress of outsourcing activities smoothly

\section{Strengthen Cooperation, and Improve Risk Manageme- nt Information System of the Logistics Outsourcing}

The two sides involved logistics outsourcing have different enterprise culture, so we must strengthen the cultural exchanges between enterprises, so that the two sides can better integrate into the market environment, strengthen communication between each other. [10] Enterprise establishes the joint risk prevention mechanism and information sharing mechanism. And through the improvement of risk management information system realize the control information risk of logistics outsourcing. Through the information technology platform, both parties collect, analysis and process for key indicators of production, transportation planning, cost, demand, it provide warning display and dynamic information management and risk response strategy for logistics outsourcing process. And ensuring the information timely, accurate, efficient, and information security management measures, so as to ensure the smooth implementation of logistics outsourcing

\section{SUMMARY}

Logistics outsourcing is the evolution of formation and development of the third party logistics enterprise and the objective demand of enterprise produced in the new market competition, development course of thirty years of enterprise logistics outsourcing confirmed that the enterprise logistics outsourcing plays an important role for enterprises to focus on the core business, their condensed utmost resource, improve the efficiency of resources. But it exists risks from various aspects in the logistics outsourcing, which generated negative impacts and results to the enterprise logistics outsourcing and even other business. Therefore, enterprise must strengthen the overall arrangement and coordination and communication in the process of logistics outsourcing, and formulate prevention strategies of outsourcing information risk suit one's measures to local conditions, in order to further enhance their own core competitive ability

\section{REFERENCES}

[1] Ying Zhi Yuan,“Enterprise Customer Relationship Management Based on the New Characteristics of International Logistics", Cooperation Economic and Technological, no. 4, pp.57-59, 2011

[2] Chen Xue,"Research on Construction of the Third Party Logistics Customer Relationship Management System Based on Supply Chain Management”, Logistics Engineering and Management , No.2, Pp.34-35, 2011.

[3] Ji Lei ,"the Third Party Logistics Enterprise Customer Relationship Management”, Operation and Management, no. 6, pp.63-65, 2011.

[4] Wu Hui Jie,“Modern Logistics Enterprisescustomer Relationship Management ”, Enterprise , no. 5, pp.245-247, 20111 
[5] Li Ru-Jing, “On Evaluation The Performance Of Supply Chain Management”, Business Economy , no. 10, pp.101-104, 2012.

[6] Li Zhi Yuan, "On the Application of Customer Relationship Management in Logistics Enterprises", Science and Technology Innovation Herald, no. 9, pp.57-59, 2010.

[7] Zhao Yang, "the third Party Logistics Enterprise Customer Relationship Management ”, Operation and Management ,no. 8, pp.57-59, 2010.
[8] Sodano V. , Verneau F. Traceability and Food Safety: Public Choice and Private Incentives [A ] . In: Schiefer G. , R ickert U

[9] ( Eds) , Quality Assurance Risk Management and Environmental Control in Agriculture and Food Supply Networks [C] Bonn: Universitat Bonn-ILB， 2004

[10] Elise Golan, Barry Krissoff, Linda Calvinand Kenneth Nelson. Traceability in the USA food supply: Economic Theory and Industry Studies[J].Agricultural Economic Report.2004,(03) 